\title{
2 方向ロケット法の試み
}

-Albumin-IgG, C 3 PA-C 3 A, SC-SIgA の分離定量法とその応用一

\author{
香 坂 隆夫・朝比奈 利憲*.小 林 登**
}

\section{【Summary】}

This communication describes a successful application of two-directional rocket method to simultaneous quantitation of various substances. Differential assay of albumin and IgG, which have different mobility and antigenicity, was found easiest, by changing the agarose/agar ratio to get an appropriate electroendosmosis of the gel. That of C 3 PA and $\mathrm{C} 3 \mathrm{~A}$, which have identical antigenicity but different mobility, was found likewise easy, for on addition of EDTA to agar, anodal migration of $\mathrm{C} 3 \mathrm{PA}$ alone took place, while $\mathrm{C} 3 \mathrm{~A}$ remained in cathodal side.

Differential assay of SC and SIgA was also successful: After transferring SC from $\beta_{1}$ region to $\alpha_{1}$-region by addition of heparin-Ca EDTA the two substances were separated in the opposite direction by changing agarose/agar ratio. The height of the rocket-shaped precipitation peaks formed in two directions was found proportional to the concentration of the antigens.

According to our postulation the effect of the polyanionic charge of heparin is a contributing factor to this effect of heparin-Ca EDTA on SC, because the electric mobility of SC was altered by other anion surfectants, and in addition, this effect was quite vulnerable to the influences of $\mathrm{pH}$ and ionic strength.

In using this method as a screening assay of saliva donors for detection of primary immunodeficiency, 2 cases of isolated IgA immunodeficiency and 2 cases of hypoglobulinemia were picked up from 16,000 infants in Shida District over a 3 year period.

In view of the significant role of SIgA in local protective mechanism, this two-directional rocket method seems to be recommended, because of its easy sampling procedure.

\section{【概 要】}

物翼の同時定量方法として 2 方向ロケット法を試み，いくつかの物質の同時測定に応用し，良好な結果を得たので報 告した.もっとも簡単なものは albumin と IgG の組合せである. 移動度も抗原性も異なる物質であり,たんに agarose と agar の比を変え， electroendosmosis を適当に調節してやることによって分離定量が可能である.つい で C 3 PA と C 3 A は, 同一抗原性を有するが，agar に EDTA を添加することによって，C 3 PA のみ陽極側に 移動し, C $3 \mathrm{~A}$ は陰極側にひかれるので同様に分離定量が可能ですった.

\section{藤枝市志太総合病院小児科}

* 同検查科

** 東京大学医学部小児科 
$\mathrm{SC}$ とIgA の分離定量は heparin-Ca EDTAを添加することによって, SC の移動度を $\beta_{1}$ 領域から $\alpha_{1}$ 領域へ 移動させた後, agar と agarose を適当に混じることにより, SC とSIgA をそれぞれ, 原点を中心に陽極側, 陰極 側に分けることによって達成された. この heparin.Ca EDTA の効果は, heparin の polyanion としての作用が関 係していると考えられる.その理由は他の陰イオン界面活性剤でも上記のような電気移動度の相違が見出され, しか もこの移動度の変化は, $\mathrm{pH}$, イオン強度の影響を強くうけるからである。

著者らは，この 2 方向 rocket 法を灾用して志太地区において喠液による液性免疫不全症の mass screening 3 年間行ってきたが, 乳児 16,000 名中 IgA 単独欠損症 2 名, 乳児一過性低 $\gamma$-globulin 血症 2 名を見出した. 㗭液による mass screening は, 試料採取の容易さ, SIgA の局所免疫の重要性を考えあわせると, 今後さらに普及してよい方法 と考えられる.

\section{I.はじめに}

ロケット法は，Laurel11) によって赛際的な方法とし て確立され，種々な蛋白の定量に用いられている．主と してスカンジナビア采の学者によって，種々の応用がな され，一度に 2 物質の定量では double rocket 法2), 同 一抗原性を有する物質の分﨎定量には，2 次元免疫電気

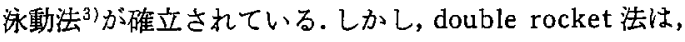
抗原性を異にする物質にしか利用できず，かつ一方の物 質の定星性半定量である。また 2 次元免疫電気泳動法 は，その分離能力にはすぐれているむのの，定量は手数 がかかり，から多数検体を測定することはできない。

著者は，同時に 2 物質を測定すると同時に，抗原性の 同一である 2 物質を電気的移動度の相違を应大寸ること によって，原点を中心に 2 方向にロケットを形成させ分 離定量する方法を開発したので報告する，その組合せ は，もっとも簡単なもので IgG と albumin であり，さ らに工夫することによってC3PA とC3A，SC とSIgA の分離定量が可能であり, mass screening の方法とし て利用している.

secretory component (SC) と secretory IgA (SIgA) が, Tomasi らによって発見され, 腸管や気道 などで外界からの侵入防禦における重要な意義づけがな されてからすでに久しい、、しかし，両者の分離定量は かならずしも容易でなく， SIgA は，IgA で測定を代用 している報告もみられるまた SC の役割はかならずし も明確でなかったが，SC 単独久損症が見出されらう，その 免疫学的役割の重要性が碓認されつつある.すすなが, SC, SIgA ともに, 外界からの, 異種蛋白の侵入に対し て選択的に分泌され，局所免疫機構として役立っている ことが明らかとされている。この両者を定量することの 意義は，たんに免疫不全症の発見ばかりでなく、これら の重要な防僖機転と疾患との関連を明らかにし，疾患の 発生機序を明らかにしうる点にもある。

著者らは免疫不全の早期発見, Polio の副作用防止の
意味から, 3 力月検診乳児の唾液中 $\mathrm{SC}, \mathrm{SIgA}$ の分別定 量を行い初歩的な結果を得たのであわせて報告する.

\section{II. 方法および対象}

agar, agarose : agar $は$ Noble agar (Difco), agarose は Wako I, Wako III (Wako 日本) または, Litexの HSIF (endosmosis free)を用いた.

泳動条件：泳動は原則として冷却装置付の電気泳動漕 を用いて行い，平板に水滴が滴下するのを防ぎ，かつ寒 天が熱をもって幹燥するのを防止した，泳動漕の buffer は, barbital buffer ( $\mathrm{pH} 8.5, \mu=0.05) に 1 \mathrm{mM} の$ EDTA を添加して使用した， rocket 法施行の際の泳動 条件は, C 3PA，C3A の場合は 8 時間, IgG, albumin PSC, SIgA の場合は 12 時間行い, 完全に gel 内の抗 体を gel 内から流しきって, そのまま乾燥後, Nigrosine 染色を行い，その rocket の高さを測定した。なお 電圧は $6 \mathrm{~V} / \mathrm{cm}$, 泳動幅は $7.5 \mathrm{~cm} \sim 12 \mathrm{~cm}$ である.

試料および抗血清の作製：抗 IgG 血清は, Dako 社 のものを用いたが, 抗 C3PA-抗 C3A 血清は, Boenisch らの方法6よより，SC, SIgA は Khayam-Bashi らの 方法7゙より，また albumin は市販の albumin human cohn fraction V を Sephadex G 200 で精製後, それ

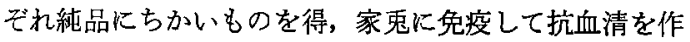
成した. 抗 SIgA 血清は, 得られたものをさらに glutaraldehyde 処理 IgA によって IgA に対する抗体を吸着 して用いた。

スタンダードは, C 3 PA は既知ヒト血清を, C 3 A は, zymosan 処理ヒト血清を用いたが，SC, SIgA, albumin，IgGはそれぞれ精製したものを作成して使用した。 抗体の力価測定は Becker 法多によった。

mass screening の対象と方法：主として藤枝市で行 っている 3 力月検診比おける乳児を対象したが，10力 月, 1 歳 6 力月, 3 歳児, 学童も検診等の際に協力をも とめ試料を得大。唾液は 3 歳までは, 主として綿棒に小 くませて採取したが，その年代以降は口の中のものをふ 
表 1 Abstract of two-directional rocket method

\begin{tabular}{|c|c|c|c|}
\hline & albumin : IgG & C3PA: C3A & $\mathrm{SC}: \mathrm{SIgA}$ \\
\hline anti-serum & $\begin{array}{l}\text { anti-albumin rabbit serum } \\
\text { (non-carbamylated) } \\
\text { ant } \mathrm{i}-\mathrm{I} \mathrm{gG} \cdot \gamma \text { chain rabbit } \\
\text { serum (carbamylated or } \\
\text { non-carbamylated) }\end{array}$ & $\begin{array}{l}\text { anti-C3PA rabbit serum } \\
\text { (carbamylated with } 0.25 \mathrm{M} \\
\mathrm{KCNO} \text { at } 44^{\circ} \mathrm{C} \text { for } 30 \mathrm{~min} \text {. } \\
\text { in pH } 7.2 \text { phosphate } \\
\text { buffer) }\end{array}$ & $\begin{array}{l}\text { anti-SC rabbit serum } \\
\text { (non-carbamylat ed) } \\
\text { ant } \mathrm{i}-\mathrm{SIgA} \text { rabbit serum } \\
\text { (treat ed with glutaraldehyde } \\
\text { IgA \& carbamylated or } \\
\text { non-carbamylated) }\end{array}$ \\
\hline gel & $\begin{array}{l}\text { Wako III agarose } 1 \% \\
\text { Lit ex agarose }\end{array}$ & Noble agar $1 \%$ & $\begin{array}{l}\text { Noble agar } 4.7 \% \\
\text { Wako agarose I } 3.3 \%\end{array}$ \\
\hline $\begin{array}{l}\text { additives to } \\
\text { gel }\end{array}$ & - & EDTA-2Na $2 \mathrm{mM}$ & $\begin{array}{l}\text { EDTA-2Na } 2 \mathrm{mM} \\
\text { heparin } 100 \mathrm{U} / \mathrm{ml}\end{array}$ \\
\hline gel buffer & $\begin{array}{l}\text { barbital buffer (pH } 8.6, \\
l l=0.025) \\
1 \mathrm{mM} \text { EDTA }\end{array}$ & $\begin{array}{l}\text { barbital buffer (pH } 8.6, \\
\prime=0.025) \\
1 \text { mM EDTA }\end{array}$ & $\begin{array}{l}\text { barbital buffer }(\mathrm{pH} 8.6, \\
\mu=0.025) \\
1 \mathrm{mM} \text { EDTA }\end{array}$ \\
\hline \multirow[t]{2}{*}{$\begin{array}{l}\text { condition of } \\
\text { elect rophoresis }\end{array}$} & $\begin{array}{l}0.5 \mathrm{~V} / \mathrm{cm} .12 \mathrm{hrs} \text {, barbital } \\
\text { buffer ( } \mathrm{pH} 8.6, \mu=0.05 \text { ) } \\
\text { cooling system }\end{array}$ & $\begin{array}{l}0.5 \mathrm{~V} / \mathrm{cm}, 8 \mathrm{hrs} \text { barbital } \\
\text { buffer ( } \mathrm{pH} 8.6, \mu=0.05) \\
\text { cooling system }\end{array}$ & $\begin{array}{l}0.5 \mathrm{~V} / \mathrm{cm}, 12 \mathrm{hrs} \text {, barbital } \\
\text { buffer ( } \mathrm{pH} 8.6, \mu=0.05) \\
\text { cooling system }\end{array}$ \\
\hline & & $\begin{array}{l}\text { stained with Nigrosine } \\
\text { after drying }\end{array}$ & \\
\hline
\end{tabular}

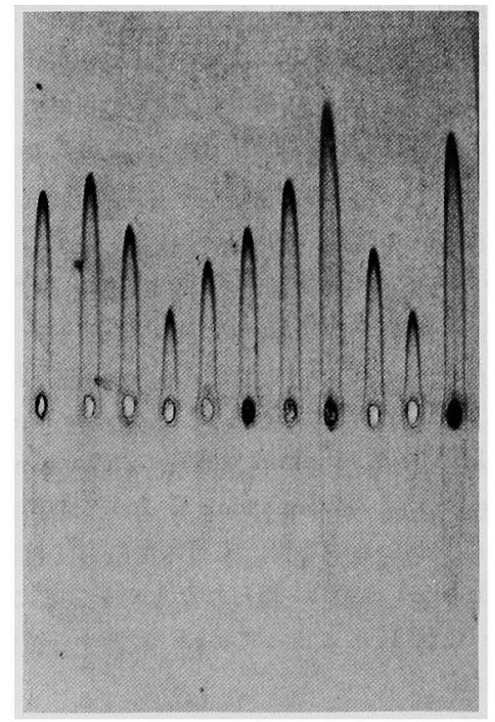

(a)

図 1 (a) Photograph of an actual plate demonstrating two-directional rocket formation of albumin and IgG in saliva collected from 1.5 year old infants.

Sample applied, $3 \mu l$; running conditi. ons specified in Table 1 .

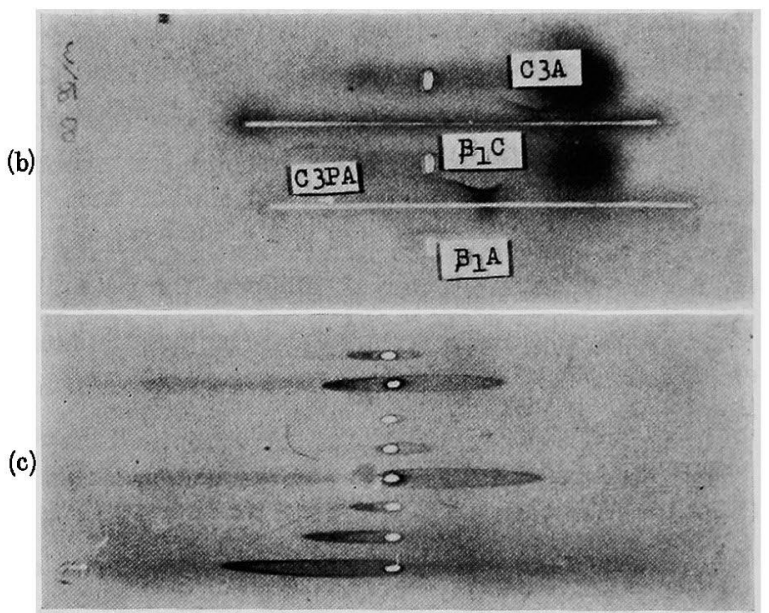

(b) Immunomigration of $\mathrm{C} 3 \mathrm{PA}$ and $\mathrm{C} 3 \mathrm{~A}$ in the presence of EDTA. C3A was found to move to $r$ region, while $\mathrm{C} 3 \mathrm{PA}$ approached the region of albumin by addition of EDTA. There was found no change in the mobilities of $\beta_{1} \mathrm{C}$ and $\beta_{1} \mathrm{~A}$. (c) Photograph of an actual plate demonstrating twodirectional rocket formation of C $3 \mathrm{PA}$ and $\mathrm{C} 3 \mathrm{~A}$. Samples applied were $1: 1,1: 4$ and $1: 8$ dilutions of fresh serum $(1 \sim 3)$, zymosan-treated serum at the same dilution $(4 \sim 6)$ and NeF-positive serum in which $\mathrm{C} 3 \mathrm{PA}$ was partially converted into $\mathrm{C} 3 \mathrm{~A}$ $(7,8)$. 
き出してもらったものを使用した．試料 24 時間以内に 測定し, 碃液の量は初期は $5 \mu l$, 現在は $3 \mu l$ を使用 し ている。

\section{III. 結 果}

\section{IgG, albumin の場合}

両者は，抗原性も移動度も異なるため，2 方向口ケッ ト法はもっとも簡単である.すなわち IgG が完全に原 点から陰極にあり，かつ albumin が陽極側によってい る寒天の条件をもとめればよいそその条件は Wako III， Litexの agrose LSA で endosmosis 0.25 であった. 実際の測定法とその様相をそれぞれ表 1, 図 1 に示した。

\section{C 3 PA, C 3A の場合}

両者は $\beta$ 領域と $\gamma$ 領域に接近しており，かつ抗原性 は，共通である。しかし，両者を agarによってできる だけ，陰極側に寄せ，EDTAを添加すると，C3PAの み陽性側へ移動する。このことによって両者の分離と 2

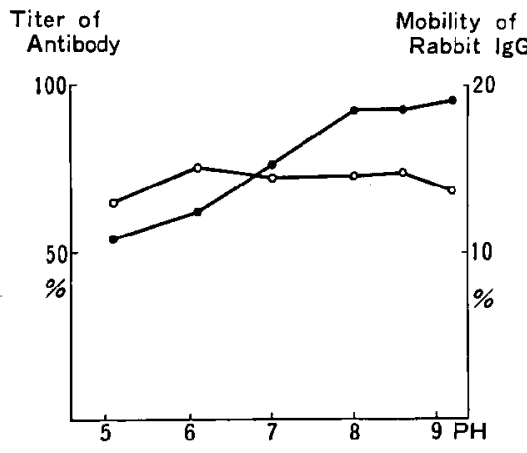

(b) 方向ロケット形成が可能であるが，agar に rocket 法 を施行した場合, 抗体も急速に陰極側へ移動するため, 陰極側の rocket はうまく形成されない，そのため，抗 体をやや陽極側へ移寸必要があり, 著者らは, carbamylationを行い至適条件をもとめた。

carbamylation の条件：陰極側に rocket を形成さ

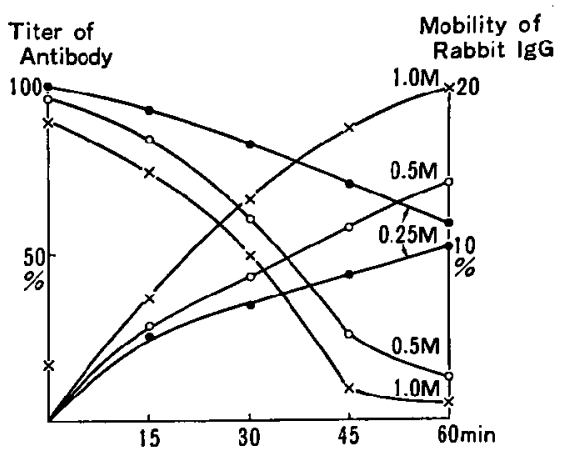

(a)

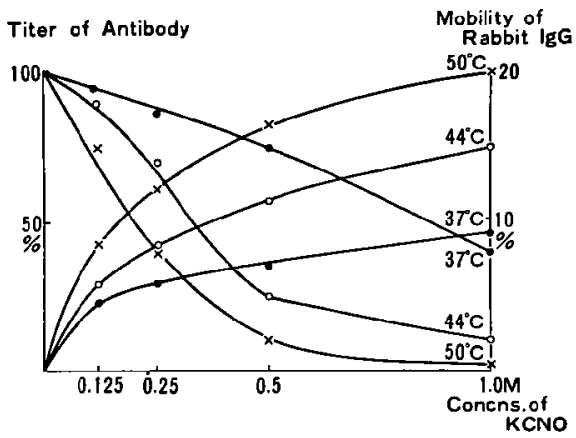

(c)

図 2 Conditions of carbamylation. The values of mobility difference between carbamylated and uncarbamylated antibody measured by cellulose acetate membrane electrophoresis are shown relatively with the absolute values of the mobility of untreated serum albu$\min$ as $100 \%$.

(a) Variations in titer and mobility difference of rabbit anti-SIgA antibody with changing temperatures and KCNO concentrations. Rabbit anti-C 3 PA antibody was incubated for 45 minutes with various concentrations of $\mathrm{KCNO}$ in $0.2 \mathrm{M}$ phosphate buffer of $\mathrm{pH}$ 8.0 at various temperatures and was titrated by Becker's method. Titer and mobility difference showed a reciprocal relationship. Inactivation of antibody proceeded with an increase in temperature or KCNO concentration.

(b) Variations in titer and mobility difference of rabbit anti-C 3 PA antibody with changing KCNO concentrations and incubation time. Rabbit anti-C 3 PA antibody was incubated at $44^{\circ} \mathrm{C}$ for various periods with various concentrations of KCNO in $0.2 \mathrm{M}$ phosphate buffer of $\mathrm{pH} 8.0$ and was titrated by Becker's method. Titer and mobility difference showed a reciprocal relationships. Inactivation of antibody procceded with an increase in $\mathrm{KCNO}$ concentration or incubation time.

(c) Variations in titer $(\cdot)$ and mobility difference ( $(0)$ of rabbit anti-C 3 PA antibody with changing $\mathrm{pH}$ and time of incubation. Rabbit anti-C 3 PA antibody was incubated at $44^{\circ} \mathrm{C}$ for various periods with $0.25 \mathrm{M} \mathrm{KCNO}$ in various buffers and was titrated by Becker's method. 
せる場合，試料蛋白の抗原と抗体が逆方向へ動くことが 望ましい，陽極側方向へ移動する抗原については問題な いのであるが，陰極側方向一移動させる抗原について は, 抗体と同方向となるため, rocket の形を sharp に し定量性をむたせるためには，抗体の移動度に変化をも たせた方がよいこの方法には，glutaraldehyde 化や carbamylationの方法があるが，著者らは，簡単にでき る方法として carbamylation を行っている. 抗体の失 活度と移動度の関係で, 最適の状態を知るために, 図 2 に示したように, $\mathrm{pH}$, 時間, 温度条件を設定した. 抗体 は carbamylation を行う際の時間, 濃度の影響を強く うけ, 高濃度の $\mathrm{KCNO}, 30$ 分以上の incubation ではか なり失活する.また $\mathrm{pH}$ は，7〜9の附近がもっとも移 動度に比し, 抗体の失活度が少ない。このようなことよ り, 抗体の carbamylation は, 抗原を carbamylation する場合と異なり, 温度は $37 \sim 44^{\circ} \mathrm{C}, \mathrm{pH} 7 \sim 9, \mathrm{KCNO}$
の浱度は $0.25 \mathrm{M}$, 時間は 30 分〜 40 分の間で行うこと が必要である.

C3PA, C3A の 2 方向ロケットの実際：C3PA, C3A は agar に EDTA を $2 \mathrm{mM}$ 添加してやることによっ て, C3PA のみを $\beta$ 領域から $\alpha$ 領域に移動させること ができるので, carbamylation した抗体含有 agar の 中で, 泳動すれば, C 3 PA は陽極側に，C 3 A は陰極 側に rocket を形成し, 両者を分離定量することができ る.その実際については，表 1 に示した.

\section{SC, SIgA の分離定量法}

SC, SIgA の分離定量をする際には, 問題点が2つあ る. 1 つは，抗 SC 血清を作成する際に SC によって免 疫して得た血清と, SIgA によって免疫して得た血清を IgA で吸着して作製した血清では，SC, SIgAに対する 親和性が異なるということを利用した点である。この点 については，すでに Brandzaeg' ${ }^{9)}$ によってくわしく検

(a) Litex agarose, heparin.Ca EDTA (-)

(b) Wako I agarose + Noble agar, heparin-Ca EDTA (-)

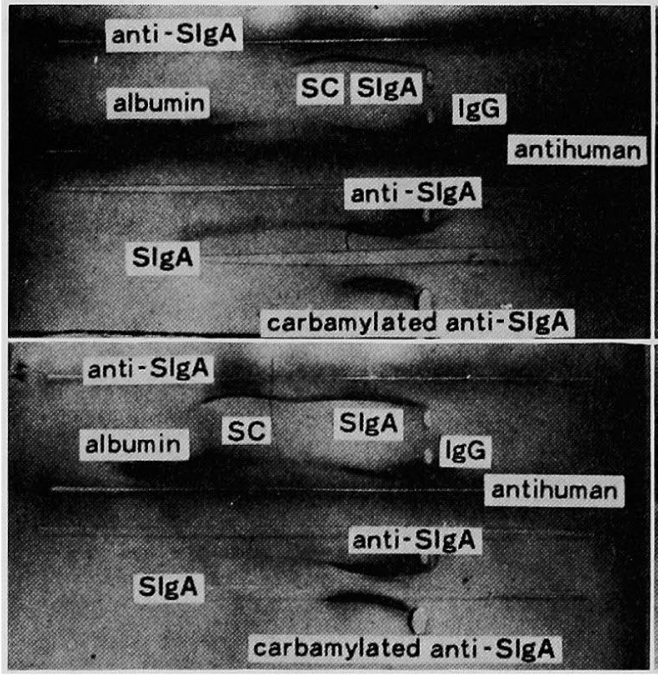

(c) Litex agarose, heparin-Ca EDTA (+)

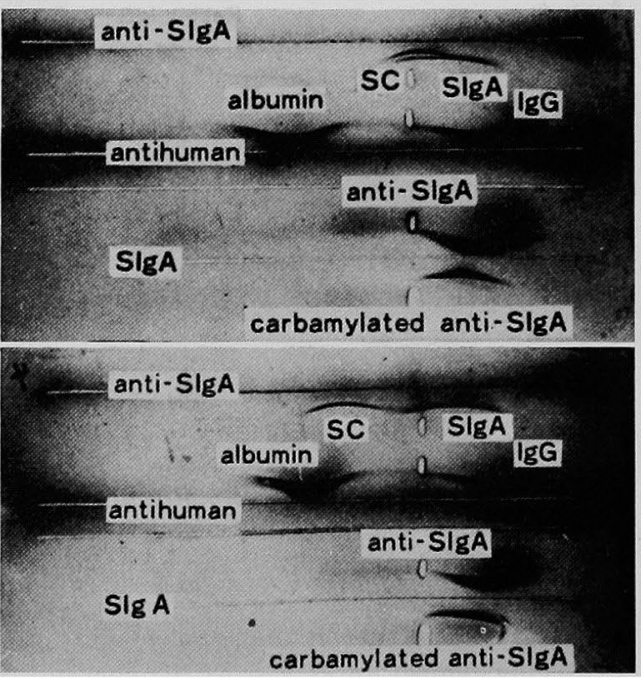

(d) Wako I agarose + Noble agar, heparin-Ca EDTA (+)

図 3 Patterns obtained on immunoelectrophoresis.

The gel contained (a) $0.8 \%$ Litex agarose HSIF, (b) $0.6 \%$ Wako I agarose and $1 \%$ Noble agar in the ratio $1: 2$, (c) $0.8 \%$ Litex agarose HSIF in the presence of heparin-Ca EDTA, and (d) $0.6 \%$ Wako I agarose and $1 \%$ Noble agar in the ratio $1: 2$ in the presence of heparinCa EDTA. Running conditions: $6 \mathrm{~V} / \mathrm{cm}, 2 \mathrm{hrs}, 0.05 \mathrm{M}$ barbital buffer of $\mathrm{pH} 8.6$. The wells were filled with a SIgA-SC mixture, IgG-albumin mixture, rabbit anti-SIgA IgG and carbamylated rabbit anti-SIgA IgG from the top. The ditches were filled with rabbit anti-SIgA serum, rabbit anti-human serum, and SIgA from the top, while the centrally placed ditch contained nothing.

Despite miscellaneous composition of agarose/agar gel mixture, no distinct separation of SIgA from SC was obtained without heparin. Rabbit IgG was partially inactivated and gained a higher anodic mobility by carbamylation. 


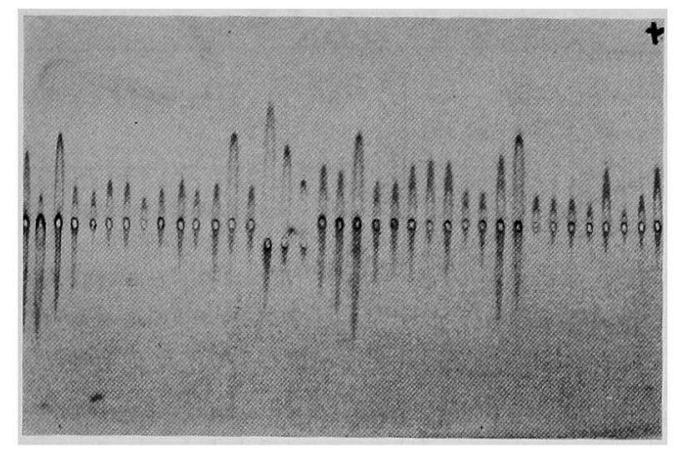

図 4 Photograph of an actual plate demonstrating two-directional rocket formation of SC and SIgA in saliva collected from 3-months old infants.

\section{討されているので省略する.}

一方, SC は $\beta$ 領域, SIgA は $\gamma$ 領域の物質であり, その移動度は，接近しており，両分物質を分離定量する ためには，両者の移動をひきはなす必要がある，その方 法としてEDTA 添加では不十分であり，さらに heparin を添加することによって, SC のみ $\alpha$ 領域に移動させる ことができた.

\section{IV. heparin-Ca EDTA の効果}

$\mathrm{pH} 8.6, \mu=0.05$ の barbital bufferを用いたagaroseagar 混合 gel $に$ heparinを添加すると， $\beta_{1}$ から $\alpha_{1}$ ま で, SC は陽極方向に移動する. しかし, 図 3 に示した ように, albumin, IgG, SIgA の移動度にはほとんど影 響を与えない。しかもこの heparin-Ca EDTA の効果 は, agar-agarose 比の相違によって生ずる electroendosmosis とまったく無関係であり, electroendosmosis free とされている Litex の agarose HSIF を用いても 生ずる.このことを利用して, agar と agarose を適当 な比率に混合して，両者を原点を中心として陽極側に SC, 陰極側に SIgA と分離することができる.この条 件は Wako I agarose : Noble agar の比が 1:1の時 であった.

\section{2 万向ロヶット法の実際}

上記のような条件のもとで，抗血清を適当量混じた寒 天平板を電気的にひいてやることにより 2 方向ロケット が完成する.このときの条件としては， $\mathrm{pH} と \mu$ および 寒天濃度をそろえることが必要である. pH が低い場合 飞 heparin EDTA 無添加の条件下では, すべての蛋白 は，陰極へ移動するが，heparin-Ca EDTA により逆に 陽極側へ移動し, $\mathrm{pH} 7.0$ 以下では $\operatorname{SIgA}$ も陽極側一移

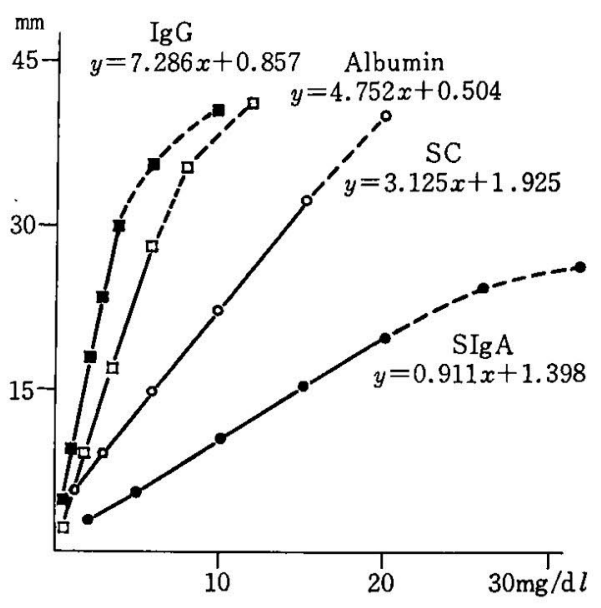

図 5 An example of standard curves of IgG, albumin, $\mathrm{SC}$ and $\mathrm{SIgA}$ in time of screening saliva donors.

When the content of antigens gets very high, the heights of rocket precipitates are not found proportional any more to the concentrations of the antigens, which are proportional to the areas of the rockets. In such cases measurement of the height gave slightly reclining lines.

動する.イオン強度 $(\mu)$ む重要で, $\mu=0.1$ 以上では, heparin による SC の移動度の変化はみられなくなり， $\mu=0.05$ 以下では, 逆に SC の移動度の陽極側への変化 が大きくなる.

著者らは, Wako I agarose : Noble agar $1: 1$, barbital buffer $\mathrm{pH} 8.6 \mu=0.025$ の条件下に抗血清を 混じた寒天平板を作製し，用いている. 泳動用 buffer は barbital buffer $\mathrm{pH} 8.6 \mu=0.05$ で，泳動時間は 12 時間, $6 \mathrm{~V} / \mathrm{cm}$, 平板の幅は $12 \mathrm{~cm}$ のものを用いている. 泳動時閒が長時間におよぶ関係上, 泳動漕は冷却装置付 きのものを使用している.

実際の方法は表 1 に, 3 力月検診時の棰液スクリー二 ングの 2 方向ロケットの写真を図 4 に示した.

\section{VI. 実際の測定上の問題之検量線}

この方法では，抗体の濃度をかえてやることによって 測定感度は異なってくる.実際の唾液中の SC 濃度は, $1 \sim 10 \mathrm{mg} / \mathrm{d} l, \mathrm{SIgA}$ の濃度は, 1〜 50 mg/d $l$ であるた め,このよらな範囲が得られるように抗 SC, 抗 SIgA 抗 血清を寒天に混じ， 2 方向ロケット法を実施して，その rocket の高さを測定して得られた standard curve を図 5 に示した。. 測定感度は SC が $0.5 \mathrm{mg} / \mathrm{d} l$ 以上, 


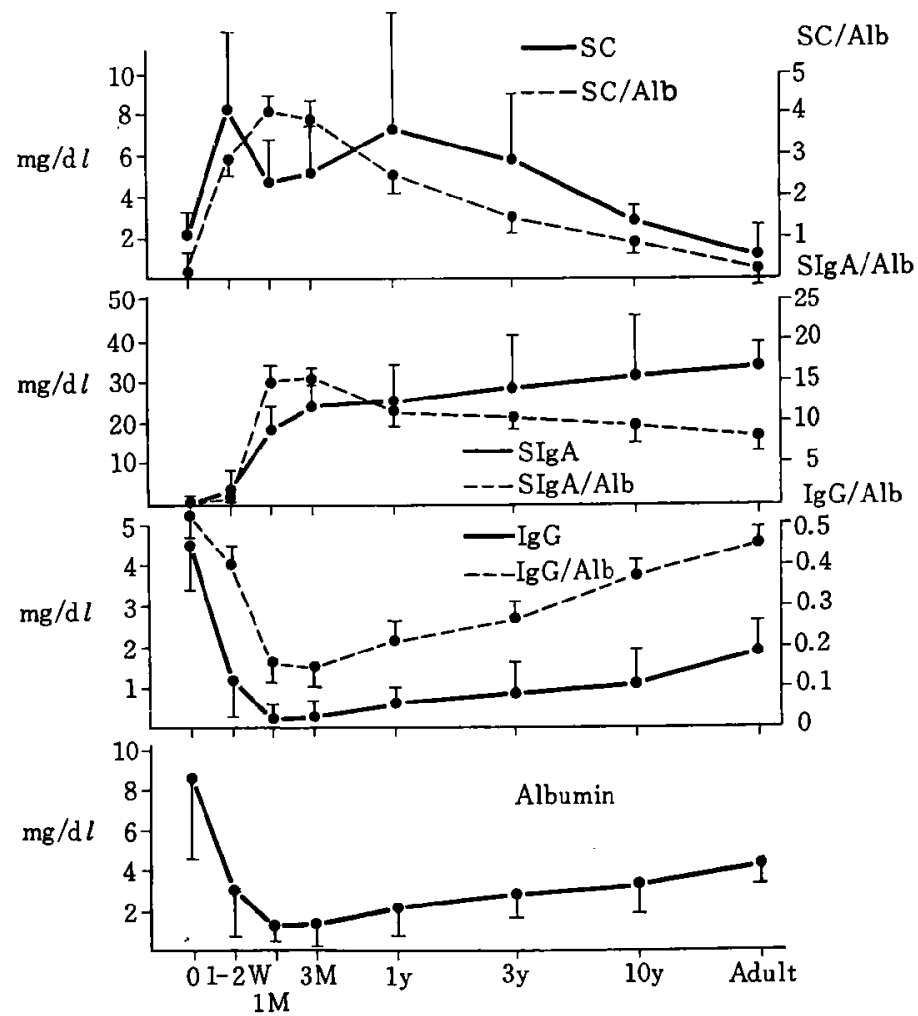

図 6 Amounts of SC, SIgA, albumin and IgG as contained in saliva plotted against age.

Each point along the curve represents salivary SC, SIgA, $\mathrm{IgG}$ and albumin concentrations (mean \pm S.D.) obtained for at least 50 subjects with the absolute values as left $y$-axis and the relative values expressed as the ratio to the absolute albumin values as right $y$-axis against age indicated horizontally.

$\mathrm{SIgA}$ が $1 \mathrm{mg} / \mathrm{d} l$ 以上であり,それぞれ, $20 \mathrm{mg} / \mathrm{d} l$ 以 上, $40 \mathrm{mg} / \mathrm{d} l$ 以上の濃度の場 合は, 面積として測定し なければ，ロケットの長さと抗原量は比例関係を示さな い. 著者らは抗原の添加量を 3〜 $5 \mu l$ としている.この 方法の問題点は, 抗 SC 血清と抗 SIgA 血清の SC, SIgA に対する親和度の差を利用して, 両者の測定範囲 を調節している点にある.したがって 2 方向にひく抗原 量が極端に異なる試料の場合には，抗原に対する親和性 ができるだけ異なり，相互に干涉しない抗血清を得る必 要がある。

\section{VII. 年齢別正常值}

図6に年㱓別の変化を示した. SC は生後 1 週間以内 に出現し，1カ月から 1 歳でピークに達する. 以降, 年 龄が進むにつれて漸減する．大人では，妊産婦や授乳中 の母親などに異常高值がみられるが, 成人男子では,
$1 \mathrm{mg} / \mathrm{d} l$ 以下である. 一方, $\operatorname{SIgA}$ は, 血清 $\operatorname{IgA} よ り$ ずっと早く出現し，生後 1 力月で成人の $2 / 3 ， 3$ 力月で 成人の $3 / 4$ の値を示し, 発達は非常に早い. 㮱液中 IgG は，血清 IgG とほほ同様の動態を示し，生後 1 力月〜 3力月で最低となり，以降成人に達するまで濑増傾向を 示す. 生下直後の高值はおそらく母親由来のものと考え られる.

唾液中の albumin は, 㗭液量と逆相関の関係を示す ようで，生後 1 週間以内は高值であるが，喠液の分泌量 が体重に比し著しく增大寸る乳児期に最低となり，以後 渐增する. 正常人の唾液を測定する際, 唾液量とその濃 度との関倸が重要であるが，試みとして albumin $1 \mathrm{mg}$ あたりに換算しなおしたるのを図6に点線で示した。 albumin あたりに換算しなおした方が偏差は小さくな る. 
表 2 Cases of salivary SIgA immunodeficiency found in our hospital.

\begin{tabular}{|c|c|c|c|c|c|c|c|c|c|c|c|c|}
\hline \multirow{2}{*}{\multicolumn{2}{|c|}{ Diagnosis }} & \multirow[b]{2}{*}{ sex age } & \multicolumn{4}{|c|}{ Serum } & \multicolumn{4}{|c|}{ Lymphocyte } & \multicolumn{2}{|c|}{ Saliva } \\
\hline & & & $\mathrm{IgG}$ & $\operatorname{Ig} A$ & $\mathrm{IgM}$ & $\operatorname{IgE}$ & Tcell & Bcell & $\mathrm{IgG} \mathrm{Fc}$ & Heper T & $\mathrm{SC}$ & $\mathrm{SIg} \mathrm{A}$ \\
\hline 1 & $\begin{array}{l}\text { agammaglobulinem ia } \\
\text { art hrit is }\end{array}$ & 今 8 & 88 & 0 & 16 & 12.5 & 90 & 0 & 2.5 & 35 & 1.0 & 0 \\
\hline 2 & agammaglobulinemia & ธิ 7 & 116 & 0 & 4 & 400 & 88 & 0 & 3.5 & 61 & 6.0 & 0 \\
\hline 3 & $\begin{array}{l}\text { ataxia telangiectasia } \\
M D+\text { ataxia }\end{array}$ & $\hat{\delta} 15$ & 1850 & 0 & 420 & 300 & 78 & 2.6 & 15.3 & 42 & 4.2 & 0 \\
\hline 4 & $\begin{array}{l}\text { select ive IgA deficiency } \\
\text { epilepsy }+ \text { infection }\end{array}$ & ริ 14 & 1610 & 5 & 270 & 300 & 80 & 7.4 & 3.9 & 19 & 9.3 & 0 \\
\hline 5 & $\begin{array}{l}\text { selective IgA deficiency } \\
\text { epilepsy }\end{array}$ & +8 & 1050 & 0 & 37 & 25以下 & 69 & 10 & 8 & 0 & 5.0 & 0 \\
\hline 6 & $\begin{array}{l}\text { select ive IgA deficiency } \\
\text { asthema }\end{array}$ & 우 13 & 2100 & 0 & 320 & 720 & 65 & 15 & 7 & 12 & 12.1 & 0 \\
\hline 7 & $\begin{array}{l}\text { select ive IgA deficiency } \\
\text { A G N }\end{array}$ & 96 & 600 & 0 & 200 & 85 & 79 & 11.2 & 4.3 & 0 & 3.5 & 0 \\
\hline 8 & $\begin{array}{l}\text { select ive IgA deficiency } \\
\text { urt icaria }\end{array}$ & f 11 & 1050 & 4 & 72 & 25以下 & 79 & 11 & 6 & & 4.5 & 0 \\
\hline 9 & select ive IgA deficiency & 車 $8 \mathrm{M}$ & 460 & 0 & 50 & 25以下 & & & & & 7.2 & 0 \\
\hline 10 & select ive IgA deficiency & of 1 & 850 & 4 & 62 & 25以下 & & & & & 4.3 & 0 \\
\hline 11 & transient hypo $\gamma$-globulinemia & 우 1 & 180 & 8 & 32 & 25以下 & 84 & 5 & 4 & & 5.0 & 0 \\
\hline 12 & transient hypo $\gamma$-globulinemia & $\hat{\delta} \quad 1$ & 190 & 7 & 44 & 25以下 & & & & & 4.2 & 0 \\
\hline 13 & $\begin{array}{l}\text { transient hypo } \gamma \text {-globulinemia } \\
\text { Food allergy }\end{array}$ & ㅇ $8 \mathrm{M}$ & 38 & 22 & 16 & 870 & 91 & 2 & 4 & & 2.5 & 0 \\
\hline 14 & $\begin{array}{l}\text { transient hypo } \gamma \text {-globulinemia } \\
\text { Letterer-Siwe synd }\end{array}$ & o 1 & 180 & 5 & 53 & 530 & 82 & 6 & 5 & & 1.0 & 0 \\
\hline 15 & Milk allergy & ㅇ 1 & 390 & 12 & 46 & 780 & 83 & 15 & 8 & & 0.8 & 0 \\
\hline
\end{tabular}

MD; mental retardation

\section{VIII. 志太地区における mass screening}

著者らは，上記の方法を用いて，志太地区の 3 力月検 診時に喠液を採取し，液性免疫不全の mass screening を実施している。昭和 52 年 2 月より 55 年 2 月まで 1 歲 6 力月児, 3 歳児, 学童にも施行し, 対象例数は計 16,000 名である.このなかより，IgA 単独欠損症 2 名, 低 $\gamma$-globulin 血症 2 名を見出しており，現在な㧍経過 観察中である. IgA 单独欠損症は, 無症状であり, 低 $\gamma$-globulin 血症 2 例む transient なるので, 現在は， いずれも，r-globulin 量は $200 \mathrm{mg} / \mathrm{d} l$ をこえている. 院内では， 1 年閒の外来入院患者上り，2名の IgA 単 独欠損症を見出した１名は urticaria を主訴として来 院し，1名は1歳より抗てんかん薬を服用している例で あった.なお SC 単独欠損症については 1 例も見出しえ なかった。

\section{IX. 考察}

同一抗原性を有する物質の分漼定量法としては，2次 元免疫電気泳動法 crossed immunoelectrophoresis ${ }^{13}$ )
が行われ，抗原性の異なる物質の同時定量法としては， double rocket 法がすで飞報告されている. 前者は, 寒 天あるいは, polyacrylamide gel で泳動後, 再度抗血 清の入った寒天で直角方向に泳動し, 陽極側に山状の沈 隆線をつくらせ, 面積の相対量を測定する方法である が, 操作が複雑なうえ, 定量性が不十分で, 陽極側に移 動する物質しか定量できないという欠点をるつ. 後者の double rocket 法は簡単であるか，抗原性と箧気移 動度がまったく異なるものについてのみ測定可能であ り，移動度の遅い方の抗原についての定量性は不十分て ある。

著者らはこれらの点を考えあわせ，陽極側と陰極側飞 同時に rocket を形成させ, 両者の定量性を改善すると ともに，抗原性の同一のものについて分離して定量する 方法を確立した、本法のポイントは, 両者の分離をよく するための手段として gel 内に EDTA-Na や EDTAheparin-Ca を混したことであり，このことによって C3PA P C 3A, SC P SIgA の移動度を変化させたこ とである.C3PA とC $3 \mathrm{~A}$ の分離定量法は nephritic factor の検出に応用でき，そのゃり方についてはすで 
に発表した ${ }^{10)}$ 。しかし，実際，生体内でC 3 A が存在し， 疾患によってなんらかの意味が見出されるかどうかは今 後の検討にまちたい，EDTA 添加によって，C 3 PA が陽極側に移動する原因については，かならずしも明確 ではないが, EDTAのキレート作用によって, gelの荷 電状態に変化をもたらすためと考えられる. heparin は 強力な陰イオン荷電をむっているが, gel 内に heparin を添加すると，C 3 PA，C 3 A ともに陽極側へ移動し， その位置はそれぞれ albumin， $\alpha_{1}$ 領域であり，2 方向 rocket 法には適していない。この heparin-Ca EDTA の作用は, $\mathrm{pH} 8.0 \sim 10, \mu=0.5$ 以下の範囲で有勃であ り, $\mathrm{pH}$ とイオン強度の影響を強くうける. また他の陰 イオン界面佸性凨でも同様の影響がみられることより， おそらく heparin の polyanion としての性質が重要 な役割を占めていると考えられる.

この方法の利点は，同一検体について同時に2つの物 質を定量できるので，睡液のように濃度にバラッキの大 きい検体では，SC，albumin など指標となる蛋白を定 量しておくことにより，SIgA，IgGなどの意味うけが 容易となる.

第 2 に，唾液のように mucoid を含み粘張力のある物

1) Laurell, C.B. : Quantitative estimation of proteins by electrophoresis in agarose gel containing antibodies. Anal. Biochem., $15: 45,1966$.

2) Laurell, C.B. : Electroimmunoassay. Scand. J. Clin. Lab. Invest., $29: 21,1972$.

3) Ganrot, P.O. : Crossed immunoelectrophoresis. Scand. J. Clin. Lab. Invest., $29: 39,1972$.

4) Tomasi, T.B. and Grey, H.M. : Structure and function of immunoglobulin A. Prog. Allergy, $16: 81,1972$.

5) Reynolds, H.Y. and Nelson, D.L. : Secretory component deficiency; a disorder of the IgA immune system. New Engl. J. Med., 294 : 351, 1976.

6) Boenisch, T. and Alper, C.A. : Isolation and properties of a glycine rich $\beta$-glycoprotein. Biochem. Biophys. Acta, 221 : 529, 1970.

7) Khayam-Bashi, H., Blanken, R.M. and Schwartz, C.L. : Chromatographic separation and purification of secretory IgA from human milk. Prep. Biochem., 7 : 225, 1977.

8) Becker, W. : Determination of antisera titres
質は, single radial immunodiffusion 法などでは, 大 きな誤差を生じやすが, rocket 法では電気的にひく ために誤差が少ない。

また, $\mathrm{pH} と$ heparin の量を調節してやることによっ て，他の蛋白にも応用しうるであるう。

著者らは液性免疫のスクリーニングとして唾液を用い て行っているが，その利点としては，まず採取が簡単で あり，児に負担がかからないので容易に行いうることが あげられる。

第 3 K, IgA K比し, SIgA の発達が早く, 3 力月児 でも，容易に異常が発見できるとである.SIgAは， 図4亿示したように生後 1〜2Wで出現しはじめ, 3 力 月児では, 成人の $2 / 3$ に達する.スクリーニングの結 果, 16,000 名中, IgA 単独久損症 2 名, 一過性低 $\gamma$. globulin 血症 2 名を見出した。 また入院外来患者を対 象としたスクリーニングでは，IgA 単独欠損症 8 名が 存在しており，おそらく6,000 8,000名に 1 名ぐらい の割合になると推定される.この值は, 欧米での報告よ り少なく, 日本人成人の 10,054 名に 1 人上りは多い。 これは人種的差異と,対象群の相違によるものであろう.

献

using the single radial immunodiffusion method. Immunochem., $6: 539,1969$.

9) Brandzaeg, P. and Gjeruldsen, S.T. : Human secretory immunoglobulins. I. Salivary secretions from individuals with normal or low Ievels of serum immunoglobulins. Scand. J. Haematol., $12: 3$, 1970.

10）香坂隆夫・赤城邦彦・榎本 武・水谷修紀・小林 登: 各種腎炎に対する heparin の効果一低補体性

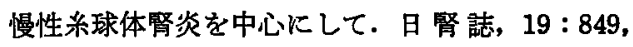
1977.

11) Holt, P.D., Tandy, N.P. and Anstee, D.J.: Screening of blood donors for IgA deficiency : a study of the donor population of south-west England. J. Clin. Path., $30: 1007,1977$.

12）加納 正·水本 ·安田典正 ·大久保康人·吉 村敬次: The frequency of IgA deficiency in 222,590 blood donors. p. 11 15 in Reports on the Investigations carried out by members of the Immunodeficiency Syndrome Research Committee of the Ministry of Health and Welfare, 1979. 